Article

\title{
Exchange Rate Effects on International Commercial Trade Competitiveness
}

\author{
Ionel Bostan $1, *(\mathbb{D})$, Carmen Toderaşcu (Sandu) ${ }^{2}$ and Bogdan-Narcis Firtescu ${ }^{2}$ \\ 1 Faculty of Law, Stefan cel Mare Univesity, 720229 Suceava, Romania \\ 2 Faculty of Economics and Business Administration, Alexandru Ioan Cuza University of Iasi, 700506 Iasi, \\ Romania; carmentoderascu@gmail.com (C.T.); firtescu@uaic.ro (B.-N.F.) \\ * Correspondence: ionel_bostan@yahoo.com
}

Received: 27 January 2018; Accepted: 30 March 2018; Published: 8 April 2018

\begin{abstract}
This study is meant to be an evaluation sustained by theoretical and empirical considerations of the exchange rate impact on international commercial trade competitiveness. In this respect, the study aims to find how the exchange rate influences Romanian competitiveness through assessing the effects generated on exports and imports. The main purpose of the study is to assess the complex action of the exchange rate on international commercial trade competitiveness in contemporaneity and the connections between these variables. The empirical part contains a regression analysis where exports and imports are dependent variables influenced by a series of determinants.
\end{abstract}

Keywords: exchange rate; economic competitiveness; exports; imports; multiple regression

\section{Introduction}

An assessment of exchange rate implications on competitiveness and international trade can be difficult to make during certain circumstances where authorities set tariffs and trade policies are influenced by political decisions such as the Brexit procedure.

Nowadays, the international trade is influenced significantly by the policies and actions that have effects on specific economic areas. Governmental authorities adopt widely measures to stimulate direct foreign investments to simulate the national imports and exports in the gross domestic product. In addition, boosting international trade is sustained through liberalization of capital dynamics by relaxing the restrictions and taxes applied to it. All these alterations have been endorsed in the context of globalization and formation of economic unions such as the European Union.

The exchange rate is an important determinant as it has deep influences on economy, financial markets and citizens. The exchange rate is referential to today's financial markets because it reflects elements of competitiveness, and its evaluation is essential as it encloses influences from a multitude of factors, but at the same time its alteration has multiple implications on external competitiveness, real economy and financial markets.

The international financial crisis affected external competitiveness and influenced competitive advantages. In today's socio-political context, the Ukrainian crisis and the restrictions imposed on Russia determined a heavy depreciation of the Russian ruble. This increased pace of contagion is due to the process of globalization expansion, but also to the liberalization of international financial markets that stimulated direct foreign investments. In this sense, it is necessary to separate speculative funds from those that aim at obtaining medium to long-time results. While speculative funds aim at financial market evolutions that reflect changes on real economy, direct foreign investment in production capacities or even services can be stimulated by creating circumstances that sustain competitive advantages. Following these contemporary circumstances, the study aims to find how the exchange rate may influence Romanian competitiveness through assessing the effects generated on exports and 
imports. Therefore, the main research objective is to determine how the exchange rate may affect the evolution of the Romanian international trade. The secondary objectives are related to identification of other determinants that have significant influences on exports and imports. The results would give the opportunity to design proper measures to improve Romanian competitiveness by focusing on the most important and relevant determinants. The study is important due to the strategic economic and political importance of Romania within Eastern Europe. In addition, the study can explain how a financial mechanism such as the exchange rate influences real economy.

\section{Literature Review}

The exchange rate impact on international commercial trade competitiveness is approached in many theoretical and empirical analyses, carried out on various countries on different periods. One of the most known approaches is the "absorbance theory", which reflects how the exchange rate has effects on both national income and international trade. According to this theory, depreciation effects will not manifest at once, but after a certain period of time, Krueger (1996). Dornbusch (2000) associates the exchange rate evolution with the rate of interest alteration. Thus, the exchange rate rapidly reacts to the rate of interest alteration ("overshooting"), but on the long term they come back to the level given by the economic basis of that state (Frankel and Wei 1993; Frankel and Rose 1996). This perspective on the exchange rate engages a temporal component, offering a perspective on the exchange rate that covers different effects depending on the period of time considered as referential. In the respective context, Klein and Shambaugh (2010) show that the exchange rate of the currency is a special rate determined by the power of the market (in addition, we could also argue that this statement has bases for a floating exchange rate or in those situations where the intervention of the bank is rare and they only aim at correcting certain imbalances that can have negative effects, and functional implications on the real economy or financial markets), which change for short periods of time. Stein and Allen (1995) go further and claim that implementation of statistical patterns on the exchange rate has been a disappointment, but these are still employed to explain the exchange rate evolution. In addition, one can add up to this affirmation that the participants to international trading and those from the financial market manifest irrationality when they make decisions (Stein and Paladino 1998). At the same time, the results are influenced by recurrent cycles of economy and the herd instinct make people react similarly in crisis situations (Ehrmann and Fratzscher 2005). Unquantifiable factors such as psychological factors, influence human behavior and, together with other determinants, affect the results of the patterns that cannot be quantifiable. This way, the evaluation of the exchange rate and influential factors confine to those quantitative variables.

The literature review approaches a general framework where exchange rate has a significant influence on the decisional process within the international trade practices, an instant reaction of the participants to international trade being possible when these fluctuations are very high, while a long-term appreciation or depreciation would influence international trade policies.

In specialized literature, it is widely acknowledged that the exchange rate volatility tends to reduce the volume of international trading. Abrahams (1980) and Thursby and Thursby (1978) have observed a negative effect of exchange rate volatility on trading, and Hooper and Kohlhagen (1978) did not signal significant effects on trading but an important effect on products and prices in services. Later on, in other studies, including those of Frankel and Rose (1996) and De Grauwe and Skudelny (1996), all economy specialists reported small or insignificant negative effects.

Some studies tried to examine reverse causality, namely whether the exchange rate volatility can be diminished by the agency of international trading. In the analysis of optimal foreign currency zone, Mundell (1996) primarily monitored this reverse relation of causality and he observed that the trade flux diminished the volatility of the exchange rate.

Over more than a decade ago, Hau (2000); Obstfeld et al. (1996) and Obstfeld and Rogoff (2000) respectively presented stochastic macro-economic patterns for open economies, with nominal inflexibilities, 
to demonstrate the fact that economic opening and volatility of the exchange rate are counter-dependent. Empirical arguments have been formulated by Hau (2000) and Calderon (2004), who confirm this relation.

Global economy experienced a growth in the level of integration of international financial markets on the dawn of 1970, which brought about changes, such as the removal of capital control and de-regulation of domestic financial markets (Goldstein and Mussa 1993). Additionally, improvement of the international communication network and informational technology led to "natural" dropping of barriers from international financial transactions, as well as obliteration of the difficult absorbance of direct foreign investment and trading (Obstfeld 1998; Baldwin and Martin 1999).

International financial liberalization was accompanied by renouncement to the international monetary system of Bretton Woods and passing to floating exchange rates of the dominant currencies or of regional monetary units.

Another important approach of specialized literature regarding the impact of exchange rate on international trading is furnished by the flexibility theory elaborated by Marshall and Lerner, which suggests that currency depreciation involves changes within the evolution of payment balance, respectively in consumer goods and prices of services involved in international trading.

Meese and Rogoff (1983) indicated that, of all the factor categories previously presented, some have a short-term influence, while others, such as economic factors, influence the exchange rate evolution in the medium to long term. Depending on these considerations, the determinants of the exchange rate evolution can be fundamental or temporary. The determinant factors, which usually have a medium to long term influence, are monetary matter, gross domestic product, rate of interest, rate of inflation and payment situation (Inci and Lu 2004). The importance of these factors is highlighted by Beckman et al. (2010), who insist that there is not an empirical efficient pattern of exchange rate evaluation by means of determinants if one considers the influence of at least one fundamental factor. The authors believe that their statement stands solid even if one accepts the absence of a long-term stable relation between the currency exchange rate and fundamental factors. Duarte and Stockman (2005) analyze the exchange rate from a cost price perspective. This way, the authors show that the definition of the exchange rate is not conditioned by the evolution of international trading, as it is independent from former, present or estimated values of macro-economic variables. Babecky et al. $(2009 ; 2010)$ illustrate the multiple positive effects of direct foreign investments in the case of countries that only recently became members. These positive effects include development and consolidation of financial markets, mending of payments' balance situations, the decrease of current account or stock account deficit, and appreciation of the effective exchange rate in a sustainable manner, respectively.

Frommel et al. (2005) showed that, for the 1973-2000 period, the inflation differential between partners from countries implicated in international trading, determined alteration of the exchange rate, and this is one of the macro-economic factors with the most significant effects on the national currency's exchange rate. In the context of a high inflation, it produces instability whose effects show in the appreciation of national currency.

In today's setting, when loans' denominations become important for assurance of efficient reimbursement, we believe that governmental and monetary authorities' actions must be based upon the following: assurance of financial stability to the detriment of indebtedness policies; stress upon short-term loans, denominated in national currency; and cautious handling of short and long-term debt denominated in foreign currency.

Bourguinat (2007) indicated three factors that contributed to built-up interest in the exchange rate and competitiveness, respectively, which influenced the approaches regarding the relation between these two variables, namely de-compartmentalization, de-regulation and de-intermediation. These factors developed after the expansion of financial market department functions such as involvement of banks in various investment operations, removal of overplus regulations that determine the occurrence of serious difficulties of financial markets' development or the de-intermediation that refers to stock market involvement in business environment financing. This matter has been previously studied by authors such as Combes (Combes et al. 2012), who analysed empirically the 
exchange rate, proving its direct effect on incoming foreign funds (foreign investments). Moreover, Héricourt and Poncet (2015), after conducting econometric studies, suggest that developing countries should be cautious regarding "relaxation" in the exchange rate and embrace of the floating exchange rate, which can be dangerous for international trading performance without a highly developed financial system.

\section{Methodology and Statistics}

Empiric analysis is based on a regression model where exports and imports are influenced by a series of variables such as exchange rate, inflation, direct foreign investments, portfolio investments and interest rate. This is the way to decide which determinants significantly influence international trading in terms of competitiveness.

The data was collected from the reports provided by the National Institute of Statistics, the National Bank of Romania, Eurostat and the World Economic Forum (2007-2014).

The methodology relies on linear regression that estimates the best "line", which is proper for our variables. Exchange rate, inflation, investments and interest rate are exogenous variables, which may influence international trade. Romanian exports and imports are endogenous variables, which indicate the competitiveness level. The regression is based on the OLS method, which implies finding the unique coefficients for which the sum of residual squares is minimal.

The model is presented below:

$$
y_{n}=\sum_{i=0}^{k} \beta_{i} x_{n i}+\varepsilon_{i}
$$

where:

$x_{i}-k$ explanatory variables,

$y_{n}$-the dependent variable.

The coefficients $\beta$ are found by minimizing the error of prediction.

The exchange rate is influenced by demand and supply, wherein the bank interventions are rare and strive for avoidance of imbalances that may destabilize the economic and financial environment. The Harmonized Index of Consumer Prices (HICP) is the one published by the European Statistics Institute (Eurostat) in 2005. Imports, exports, direct foreign investments and portfolio investments are all components of the payment balance available on the official webpage of the Romanian National Bank (BNR). To assure the robustness of the model, specific lags have been added. Rates of interest are associated with the new credits, according to calculations made by the Romanian National Bank, BNR Regulation no. 31/2011, respectively. According to art. 17, letter D of BNR Regulation no. $4 / 2014$, a new credit contract refers to all the new agreements concluded between an establishment or non-financial company and the reporting agent. New contracts are comprised of all of the financial contracts that mention for the first time the deposit or credit rate of interest and all the re-negotiations of the existent deposit or credit contracts. The computation basis used by BNR specialists does not include credits with deferent payments of installment and those credits destined for restructuring the allotted debt in the sense of adjusting the rates of interest to market conditions. In addition, the computation basis is not comprised of other specific situations such as overdrafts, revolving loans and credit card debt. The study of Romanian competitiveness and its implications on monetary and commercial policies could represent basis to other deciders from similar countries in Central and Eastern Europe (such as Bulgaria, Poland, Hungary or the Czech Republic).

The time period analyzed starts from January 2007, the month when Romania became a member of the European Union, to August 2014. Therefore, the study covers an 8-year period, both recession and economic recovery, and demonstrates how the exchange rate evolves and influences other variables within different economic circumstances. We also intended to analyze the crises and any available data post-crises periods, when the international commercial trade and competitiveness were affected. 
We wanted to demonstrate how the exchange rate evolves and influences the dependent variables Imports and Exports. The time series used in the empirical analyses are presented in Figure 1.

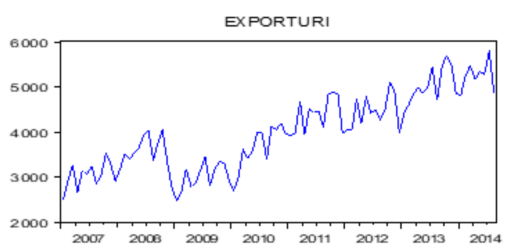

RD
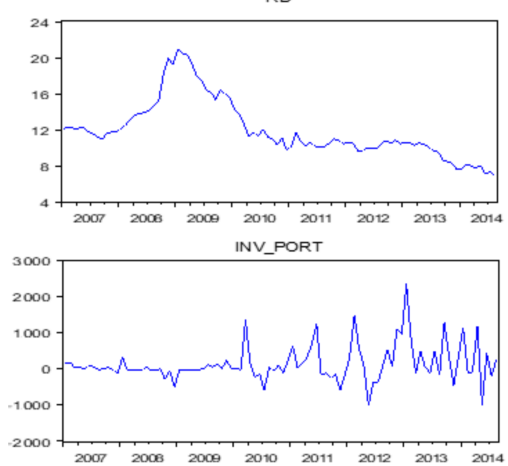

IMPORTURI

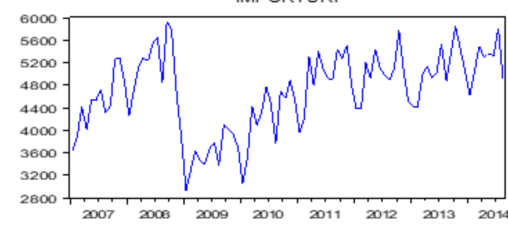

HCPI

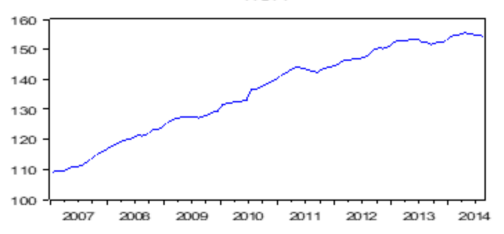

CURS

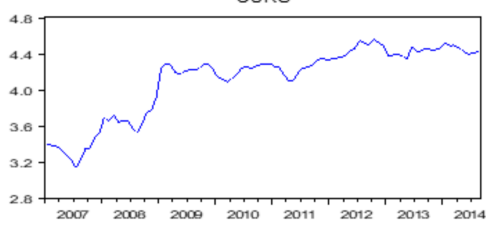

INV_DIR

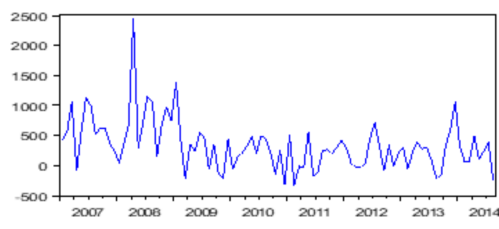

Figure 1. Variables' Time Series between January 2007 and August 2014.

Implementation of the regression model is preceded by a stationary analysis of the aforementioned time periods by means of stationary tests or the so-called "unit-root tests" developed by Augmented Dickey-Fuller and Phillips-Perron. This stationary characteristic indicates that a time series has a relatively constant evolution on the average impacts that is not permanent, and fluctuation is constant as time goes by. Results of Augmented Dickey-Fuller and Phillips-Perron stationary tests are illustrated in Table 1.

Table 1. Results of Augmented-Dickey-Fuller and Phillips-Perron stationarity tests.

\begin{tabular}{|c|c|c|c|c|}
\hline \multirow{2}{*}{ Time Series } & \multicolumn{2}{|c|}{ Augmented Dickey-Fuller } & \multicolumn{2}{|c|}{ Phillip-Perron } \\
\hline & $t$-Statistic & Prob. * & Adj. $t$-Statistic & Prob. * \\
\hline $\begin{array}{l}\text { Exchange rate } \\
\text { (L_CURS) }\end{array}$ & -1.996859 & 0.2878 & 1.216956 & 0.9420 \\
\hline $\begin{array}{l}\text { Exchange rate-first difference } \\
\text { (DL_CURS) }\end{array}$ & -6.835113 & 0.0000 & -6.835113 & 0.0000 \\
\hline $\begin{array}{c}\text { Exports } \\
(\text { L_EXPORTS })\end{array}$ & -5.152078 & 0.0003 & -5.129065 & 0.0003 \\
\hline $\begin{array}{c}\text { Imports } \\
\text { (L_IMPORTURI) }\end{array}$ & -3.637172 & 0.0068 & -3.563477 & 0.0084 \\
\hline $\begin{array}{l}\text { Harmonized Index of Consumer Prices } \\
\text { (L_HCPI) }\end{array}$ & -3.231196 & 0.0213 & -2.780967 & 0.0650 \\
\hline $\begin{array}{l}\text { Harmonized Index of Consumer Prices-first difference } \\
\text { (DL_HCPI) }\end{array}$ & - & - & -6.912854 & 0.0000 \\
\hline $\begin{array}{l}\text { Foreign Direct Investments } \\
\text { (L_INV_DIR) }\end{array}$ & -8.249263 & 0.0000 & -8.355689 & 0.0000 \\
\hline $\begin{array}{l}\text { Portfolio Investments } \\
\quad \text { (L_INV_PORT) }\end{array}$ & -8.094876 & 0.0000 & -26.91214 & 0.0000 \\
\hline $\begin{array}{l}\text { Interest Rate } \\
\quad(\text { L_RD) }\end{array}$ & -1.095434 & 0.2461 & -9.402505 & 0.0000 \\
\hline $\begin{array}{l}\text { Interest Rate-first difference } \\
\text { (DL_RD) }\end{array}$ & -9.215724 & 0.0000 & - & - \\
\hline
\end{tabular}

Source: Authors' own calculation. 
The research is based on monthly data; we also tested variables with an annual frequency, but we re-oriented to a monthly frequency due to its robustness. The time series have been log transformed to formulate different measurements. From the information provided by the previous table, it results that the harmonized index of consumer prices, the rate of interest and the exchange rate are non-stationary variables and first-class integrals. The harmonized index of consumer prices is stationary according to the results of the ADF test and non-stationary test according to the results of the Phillips-Perron test. For this reason, the exchange rate and the rate of interest will be used as the main difference. All of the variables were tested to confirm the lack of autocorrelation. We tested the lags in order to determine the most appropriate number that has statistical relevance for our model; at $5 \%$ level of significance, the connections are considered very strong, whereas, at $10 \%$ level of significance, the connection is weaker. The OLS technique was applied, as it is a common model in the literature that approach the effects of exchange rate change on competitiveness and international trade; in addition, our results indicated that an OLS is a proper model that can explain the relationship between our endogenous and exogenous variables.

\section{Empirical Results Regarding Exports and Imports}

The regression model that approaches exports through a dependent variable position is represented in Table 2. Empiric results show that, for influences manifested on exports, only particular significant lags are statistically identified.

Table 2. Regression model-Exports as dependent variables.

\begin{tabular}{|c|c|c|c|c|}
\hline Dependent Variable: Exports (L_EXPORTURI) & & & & \\
\hline \multicolumn{5}{|l|}{$\begin{array}{l}\text { Method: Least Squares } \\
\text { Date: 05/24/15 Time: 15:22 } \\
\text { Sample (adjusted): 2007M07 2014M08 } \\
\text { Included observations: } 86 \text { after adjustments }\end{array}$} \\
\hline Variable & Coefficient & Std. Error & $t$-Statistic & Prob. \\
\hline $\begin{array}{c}\text { Exchange Rate-first difference, } 2 \text { lags } \\
\text { DL CURS }(-2)\end{array}$ & -1.359792 & 0.662822 & -2.051520 & 0.0435 \\
\hline $\begin{array}{c}\text { Interest Rate-first difference, } 3 \text { lags } \\
\text { DL_RD }(-3)\end{array}$ & -0.719300 & 0.209082 & -3.440279 & 0.0009 \\
\hline $\begin{array}{l}\text { Harmonized Index of Consumer Prices, } 3 \text { lags } \\
\text { L_HCPI }(-3)\end{array}$ & 1.459683 & 0.113704 & 12.83754 & 0.0000 \\
\hline $\begin{array}{c}\text { Imports, } 2 \text { lags } \\
\text { L_IMPORTURI }(-2)\end{array}$ & 0.377479 & 0.074829 & 5.044568 & 0.0000 \\
\hline $\begin{array}{l}\text { Foreign Direct Investments, } 4 \text { lags } \\
\text { L_INV_DIR }(-4)\end{array}$ & 0.006442 & 0.002649 & 2.432006 & 0.0173 \\
\hline $\begin{array}{c}\text { Portfolio Investments, } 6 \text { lags } \\
\text { L_INV_PORT }(-6)\end{array}$ & 0.005709 & 0.002291 & 2.491675 & 0.0148 \\
\hline Constant $\mathrm{C}$ & -2.090857 & 0.683972 & -3.056932 & 0.0031 \\
\hline$R$-squared & 0.800508 & \multicolumn{2}{|c|}{ Mean dependent var } & 8.289115 \\
\hline Adjusted $R$-squared & 0.785357 & \multicolumn{2}{|c|}{ S.D. dependent var } & 0.211748 \\
\hline S.E. of regression & 0.098102 & \multicolumn{2}{|c|}{ Akaike info criterion } & -1.727729 \\
\hline Sum squared resid & 0.760295 & \multicolumn{2}{|c|}{ Schwarz criterion } & -1.527956 \\
\hline Log likelihood & 81.29233 & \multicolumn{2}{|c|}{ Hannan-Quinn criter. } & -1.647329 \\
\hline F-statistic & 52.83436 & \multicolumn{2}{|c|}{ Durbin-Watson stat } & 1.557386 \\
\hline $\operatorname{Prob}(F$-statistic) & 0.000000 & & & \\
\hline
\end{tabular}

Source: Authors' own calculation.

The results for the independent variables are statistically significant (prob. values are below 0.05 ). The influence of exchange rate manifests on exports after approximately two months. When exchange rate rises with one unit (national currency depreciation), it paradoxically carries off the dropping of export volume (decreasing it with a value of -1.359792 , having a 0.662822 standard error-Std. Error).

The result indicates that exports' competitiveness is no longer influenced by the exchange rate. An ascending alteration of inflation with one unit also reflects on the increase of exports. A rate of 
interest decrease implies financial resources that are more accessible for producers, with consequences on exports' increase. The results show that the raise of the interest rate with one unit negatively influences the evolution of exports (the value is -0.719300 with $0.209082 \mathrm{Std}$. Error).

Increase of imports (with one unit) comes together with simultaneous increase of exports with an estimated value of 0.377479 , having a standard error estimated at 0.074829 , indicating that international trading modification is synchronized both with exports and imports. Development of direct foreign investments and portfolio investments (raise with one unit) is related to increase of exports with a value of 0.006442 (with a $0.002649 \mathrm{Std}$. Error), but the index numbers have low values and show mostly an influence of circumstantial factors.

The estimated pattern follows the existent evolution of exports (Figure 2) and bigger differences were registered during the financial crisis, respectively at the end of 2008 and 2009. In the case of imports, the exchange rate has a weaker influence that is visible after only three months, the relation between variables being reversed. Depreciation of national currency diminishes the competitiveness of foreign products, and imports are negatively influenced. From this perspective, it results that exports' competitiveness is not affected by depreciation of national currency. However, then, the exchange rate appreciation engages a high perceptivity of the importers.

Decrease in the rate of interest with one unit leads to increasing of imports, and the negative relation is also identified in the case of the harmonized index of consumer prices. In the following chart, the first line with scale values between -0.3 to 0.2 represents the residuals of the model, while the following two lines with values on the scale from 7.8 to 8.8 characterize the fitted and actual values, respectively.

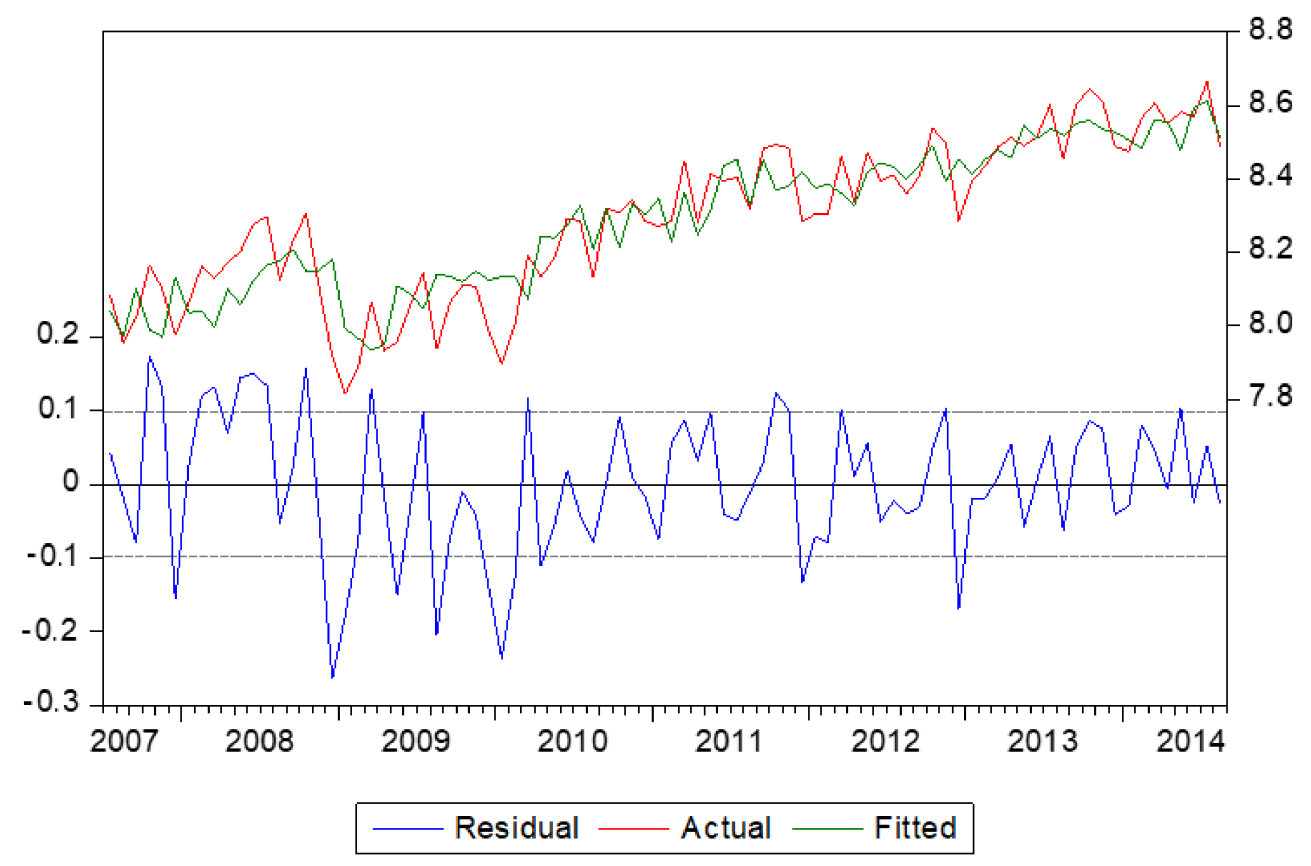

Figure 2. Actual, fitted and residuals of exports' evolution.

The results of the regression pattern with imports as dependent variables are illustrated in Table 3. 
Table 3. Regression model-Imports as dependent variables.

\begin{tabular}{|c|c|c|c|c|}
\hline \multicolumn{5}{|l|}{ Dependent Variable: Imports (L_IMPORTURI) } \\
\hline \multicolumn{5}{|l|}{ Method: Least Squares } \\
\hline \multicolumn{5}{|l|}{ Date: $05 / 24 / 15$ Time: $15: 26$} \\
\hline \multicolumn{5}{|l|}{ Sample (adjusted): 2007M06 2014M08 } \\
\hline \multicolumn{5}{|l|}{ Included observations: 87 after adjustments } \\
\hline Variable & Coefficient & Std. Error & $t$-Statistic & Prob. \\
\hline $\begin{array}{c}\text { Exchange Rate-first difference, } 3 \text { lags } \\
\text { DL_CURS }(-3)\end{array}$ & -1.400533 & 0.801111 & -1.748238 & 0.0843 \\
\hline $\begin{array}{c}\text { Interest Rate—first difference, } 3 \text { lags } \\
\text { DL_RD }(-3)\end{array}$ & -0.582154 & 0.261197 & -2.228789 & 0.0286 \\
\hline $\begin{array}{c}\text { Harmonized Index of Consumer Prices, } 3 \text { lags } \\
\text { L_HCPI }(-3)\end{array}$ & -0.662125 & 0.228646 & -2.895848 & 0.0049 \\
\hline $\begin{array}{c}\text { Exports, } 2 \text { lags } \\
\text { L_EXPORTURI }(-2)\end{array}$ & 0.682352 & 0.111969 & 6.094109 & 0.0000 \\
\hline $\begin{array}{l}\text { Foreign Direct Investments, } 3 \text { lags } \\
\text { L_INV_DIR }(-3)\end{array}$ & 0.005363 & 0.003168 & 1.692714 & 0.0944 \\
\hline $\begin{array}{l}\text { Portfolio Investments, } 5 \text { lags } \\
\text { L_INV_PORT }(-5)\end{array}$ & 0.002415 & 0.002809 & 0.859577 & 0.3926 \\
\hline Constant C & 6.033429 & 0.623786 & 9.672270 & 0.0000 \\
\hline$R$-squared & 0.453046 & \multicolumn{2}{|c|}{ Mean dependent var } & 8.448891 \\
\hline Adjusted $R$-squared & 0.412024 & \multicolumn{2}{|c|}{ S.D. dependent var } & 0.156746 \\
\hline S.E. of regression & 0.120192 & \multicolumn{2}{|c|}{ Akaike info criterion } & -1.322413 \\
\hline Sum squared resid & 1.155691 & \multicolumn{2}{|c|}{ Schwarz criterion } & -1.124007 \\
\hline Log likelihood & 64.52496 & \multicolumn{2}{|c|}{ Hannan-Quinn criter. } & -1.242521 \\
\hline$F$-statistic & 11.04408 & \multicolumn{2}{|c|}{ Durbin-Watson stat } & 1.147541 \\
\hline $\operatorname{Prob}(F$-statistic) & 0.000000 & & & \\
\hline
\end{tabular}

Source: Authors' own calculation.

The results suggest that the raise with one unit of the exchange rate, interest rate and harmonized index decreases imports with -1.400533 (0.801111), $-0.582154(0.261197)$ and $-0.662125(0.228646)$ respectively, while exports, foreign direct investments and portfolio investments positively influence the dependent variable (the values are $0.682352(0.111969), 0.005363(0.003168)$, and respectively 0.002415 (0.002809), standard errors being indicated in parentheses).

The most significant differences between the regression pattern of imports and the existent evolution of time series are identified within the financial crisis period, respectively from 2008 until 2010, during the financial crisis, upon a general decrease of international trading (Figure 3). In the chart, the first line with scale values between -0.3 to 0.3 represents the residuals of the model, while the following two lines with values on the scale from 7.8 to 8.8 characterize the fitted and actual values of the model.

The empirical analysis indicates that exchange rate depreciation is not a sufficient stimulus for higher exports' volume, whereas imports decrease. The statistical results are evidence of the reduced influence of exchange rate on the competitiveness of the Romanian goods, whereas, for the foreign goods, depreciation is a significant factor that affects their attractiveness for the domestic market. Therefore, most measures should be focused on improving the competitiveness through other channels, besides the "traditional" exchange rate. 


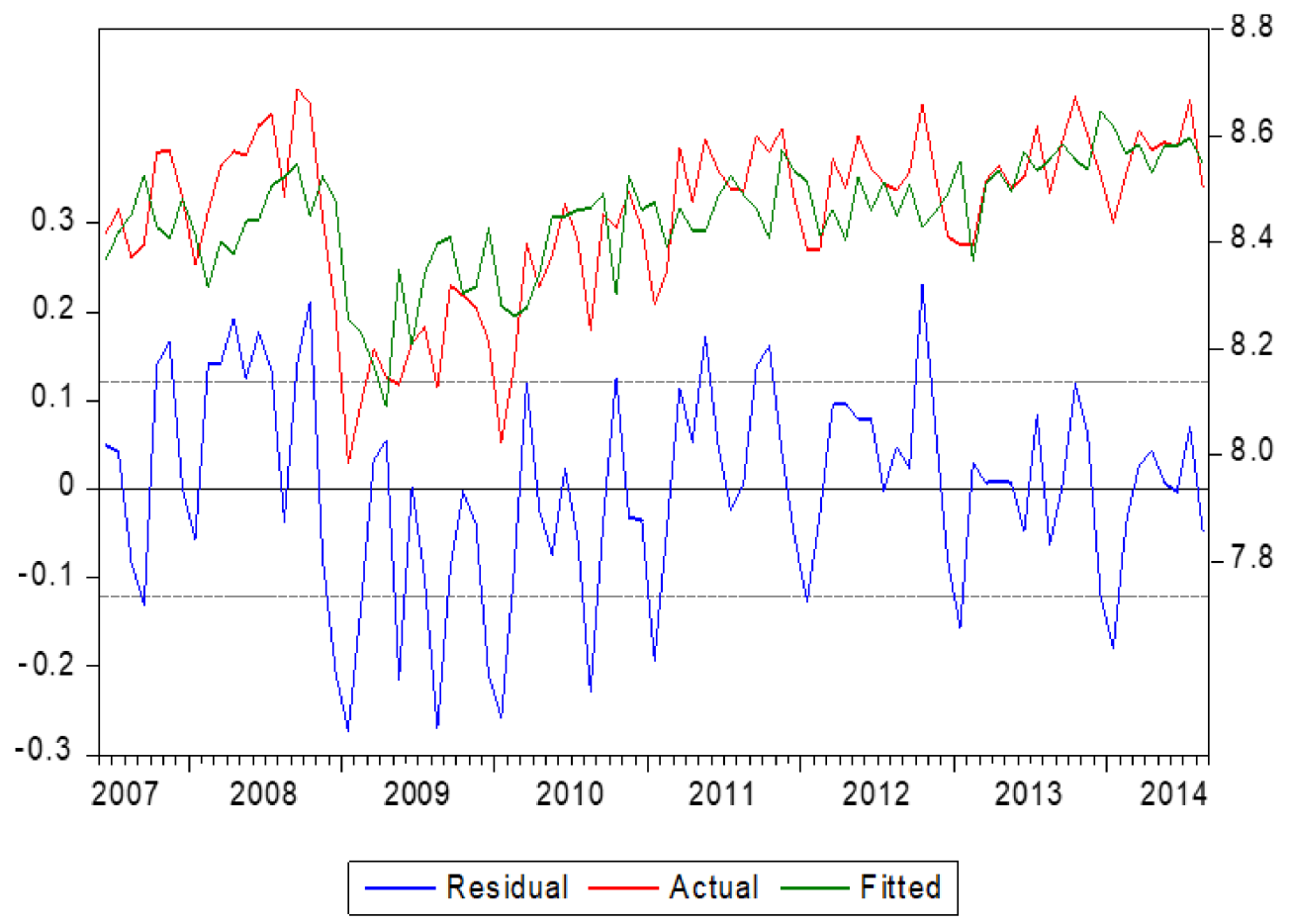

Figure 3. Actual, fitted and residuals of imports' evolution.

\section{Conclusions}

The exchange rate is an important determinant of competitiveness, as there are many trade partners from abroad, and the receipts and payments are correlated with the evolution of the currency market. When the exchange rate of the national currency is stable, it may be a factor that influences competitiveness because its evolution may attract a high trust in usage of that currency.

Economic collaboration areas draw in a tendency of economic opening of national markets that will then have alternatives regarding the availability of production factors, but also regarding the economic outlet that is now larger and is able to supply for even more consumers. These economic collaboration areas represent a frame wherewith a financial integration is sustained alongside of significant increase of amounts wound by a currency that is not the national currency. In this context, we conclude that the national currency exchange ratio becomes an impulse for the increase or decrease of international trading volume, and it is a determinant for short-term competitiveness.

In the case of Romania, the influence of the exchange rate manifests on exports after approximately two months. When the exchange rate increases (national currency depreciation), it paradoxically entrains a decrease in the exports' volume. The results indicate that exports no longer have a competitiveness influenced by the exchange rate. In addition, an inflation altered by accession reflects on the increase in exports. Decrease of the interest rate implies financial resources that are more accessible to producers, affecting the exports' increase. Increase of imports is always accompanied by the increase of exports, indicating that international trading modification is concomitant both for imports and exports. Increase of direct foreign investments and portfolio investments is associated with exports' increment, but the indices have low values and show instead an influence of circumstantial factors.

The estimated pattern follows the real evolution of exports, bigger differences being observed during the financial crisis, respectively, at the end of 2008 and 2009.

In the case of imports, the exchange rate has weaker influence, visible only after three months, the relation between variables being reverse. National currency depreciation diminishes the competitiveness of foreign products, imports being negatively influenced. From that perspective, it results in exports not 
being affected by the national currency depreciation, in terms of competitiveness. Instead, the increase of exchange rate entrains a high perceptiveness of Romanian importers. The decrease of the interest rate encourages exports, a negative relation being also identified in the case of the harmonized index of consumer prices.

The most significant differences between the regression pattern associated with imports and the real evolution of time series are identified during the financial crisis, from 2008 to 2010, respectively, overlapping a general decrease in international trading. As a future research direction, the existence of possible sector differences could be taken into consideration.

Acknowledgments: All sources of funding of the study should be disclosed. Please clearly indicate grants that you have received in support of your research work. Clearly state if you received funds for covering the costs to publish in open access.

Author Contributions: The authors' contributions were equal. Ionel Bostan reviewed the literature, designed the research, performed the analysis and drew conclusions. Carmen Toderascu (Sandu) discussed the data and the analysis and edited the paper. Bogdan Firtescu collected and discussed the data and the analysis and performed the paper editing. All authors have read and approved the final manuscript.

Conflicts of Interest: The authors declare no conflict of interest.

\section{References}

Abrahams, Richard K. 1980. Actual and Potential Trade Flows with Flexible Exchange Rates. Federal Reserve Bank of Kansas City Working Paper; Kansas City: Federal Reserve Bank of Kansas City, pp. 800-1.

Babecky, Jan, Aleš Buliřr, and Kateřina Šmídková. 2009. EU Member States: Is FDI a Mixed Blessing? In Five Years of an Enlarged EU. Berlin/Heidelberg: Springer.

Babecky, Jan, Aleš Buliřr, and Kateřina Šmídková. 2010. Sustainable Real Exchange Rates in The New EU Member States: Is FDI a Mixed Blessing? In Five Years of an Enlarged EU. European Economy Economic Papers; Berlin/Heidelberg: Springer, vol. 368, p. 77.

Baldwin, Richard E., and Philippe Martin. 1999. Two Waves of Globalisation: Superficial Similarities, Fundamental Differences. NBER Working Paper; Cambridge: National Bureau of Economic Research.

Beckman, Joscha, Ansgar Belke, and Michael Kühl. 2010. The Dollar-Euro Exchange-Rate and Macroeconomic Fundamentals: A Time-Varying Coefficient Approach. Review of World Economics 147: 11-40. [CrossRef]

Bourguinat, Henri. 2007. Finance Internationale. Paris: Presses Universitaires de France.

Calderon, César. 2004. Trade Openess and Real Exchange Rate Volatility. Panel Date Evidence. Central Bank of Chile Working Paper; Santiago: Banco Central de Chile.

Combes, Jean-Louis, Tidiane Kinda, and Patrick Plane. 2012. Capital flows, exchange rate flexibility, and the real exchange rate. Journal of Macroeconomics 34: 1034-43. [CrossRef]

De Grauwe, Paul, and Frauke Skudelny. 1996. The impact of EMU on trade flows. Weltwirtschaftliches Archiv-Review of World Economics 136: 381-402. [CrossRef]

Dornbusch, R. 2000. Financial Crises, Exchange Rate Arrangements, and the IMF. In The Paradoxes of Unintended Consequences, in Honor of George Soros. Edited by Lord Dahrendorf, Yehuda Elkana, Aryeh Neier. William Newton-Smith and Istvan Rev. Budapest: Central European University Press.

Duarte, Margarida, and Alan C. Stockman. 2005. Rational Speculation and Exchange Rates. Journal of Monetary Economics 52: 3-29. [CrossRef]

Ehrmann, Michael, and Marcel Fratzscher. 2005. Exchange Rate and Fundamentals: New Evidence from Real-time Data. Journal of International Money and Finance 24: 317-41. [CrossRef]

Frankel, Jeffrey A., and Andrew K. Rose. 1996. Currency Crashes in Emerging Markets: An Empirical Treatment. Journal of International Economics 41: 351-66. [CrossRef]

Frankel, Jeffrey A., and Shang-Jin Wei. 1993. Trade Blocs and Currency Blocs. NBER Working Paper; Cambridge, MA, USA: National Bureau of Economic Research, vol. 4335.

Frommel, Michael, Ronald MacDonald, and Lukas Menkhoff. 2005. Markov Switching Regimes in a Monetary Exchange Rate Model. Economic Modelling 22: 485-502. [CrossRef]

Hau, Harald. 2000. Real exchange rate volatility and economic openess: Theory and evidences. Journal of Money Credit and Banking 34: 611-30. [CrossRef] 
Héricourt, Jérôme, and Sandra Poncet. 2015. Exchange Rate Volatility, Financial Constraints, and Trade: Empirical Evidence from Chinese Firms. The World Bank Economic Review 29: 550-78. [CrossRef]

Hooper, Peter, and Steven W. Kohlhagen. 1978. The effect of exchange rate uncertainty on the prices and volume of international trade. Journal of International Economics 8: 483-511. [CrossRef]

Inci, Ahmet Can, and Biao Lu. 2004. Exchange rates and interest rates: Can term structure models explain currency movements? Journal of Economic Dynamics \& Control 28: 1595-624.

Klein, Michael W., and Jay C. Shambaugh. 2010. Exchange Rate Regimes in the Modern Era. Cambridge: The MIT Press.

Krueger, Anne O. 1996. Determinarea Cursului Valutar. Timișoara: Editura Sedona.

Meese, Richard A., and Kenneth Rogoff. 1983. Empirical Exchange-Rate Models of the Seventies-Do They Fit out of Sample. Journal of International Economics 14: 3-24. [CrossRef]

Mundell, Robert A. 1996. A theory of Optimal Currency Areas. American Economic Review 51: 657-65.

Goldstein, Morris, and Michael Mussa. 1993. The Integration of World Capital Markets. Paper presented at the Economic Policy Symposium, Jackson Hole, WY, USA, August 19-21; pp. 245-330.

Obstfeld, Maurice. 1998. The Global Capital Market: Benefactor or Menace? Journal of Economic Perspectives 12: 9-30. [CrossRef]

Obstfeld, Maurice, and Kenneth Rogoff. 2000. New Directions for Stochastic Open Economy Models. Journal of International Economics 50: 117-53. [CrossRef]

Obstfeld, Maurice, Kenneth S. Rogoff, and Simon Wren-lewis. 1996. Foundations of International Macroeconomics. Cambridge: MIT Press.

Stein, Jerome L., and Polly Reynolds Allen. 1995. Fundamental Determinants of Exchange Rates. Wotton-under-Edge: Clarendon Press.

Stein, Jerome L., and Giovanna Paladino. 1998. Recent Developments in International Finance: A Guide Research. Journal of Banking $\mathcal{E}$ Finance 21: 16851-720.

Thursby, Jerry G., and Marie C. Thursby. 1978. Bilateral trade flows, the Linder hypothesis and exchange risk. The Review of Economics and Statistics 69: 488-95. [CrossRef]

(C) 2018 by the authors. Licensee MDPI, Basel, Switzerland. This article is an open access article distributed under the terms and conditions of the Creative Commons Attribution (CC BY) license (http:/ / creativecommons.org/licenses/by/4.0/). 